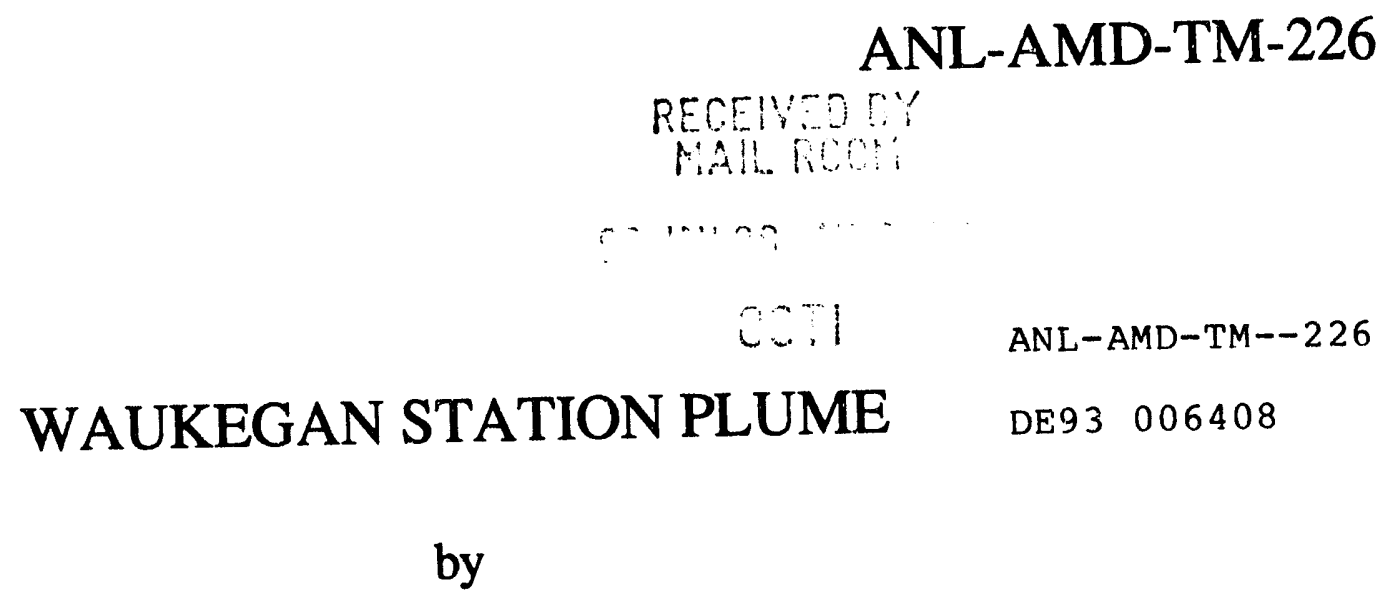

I. K. Abu-Shumays

DISCLAIMER

This report was prepared as an account of work sponsored by an agency of the United States Government. Neither the United States Government nor any agency thereof, nor any of their employees, makes any warranty, express or implied, or assumes any legal liability or responsibility for the accuracy, completeness, or usefulness of any information, apparatus, product, or process disclosed, or represents that its use would not infringe privately owned rights. Reference herein to any specific commercial product, process, or service by trade name, trademark, manufacturer, or otherwise does not necessarily constitute or imply its endorsement, recommendation, or favoring by the United States Government or any agency thereof. The views and opinions of authors expressed herein do not necessarily state or reflect those of the United States Government or any agency thereof.

\author{
ARGONNE NATIONAL LABORATORY \\ 9700 S. Cass Avenue \\ Argorıne, Illinois 60439 \\ Operated by \\ The University of Chicago under \\ Contract W-31-109-Eng-38 \\ for the U.S. Atomic Energy Commission
}

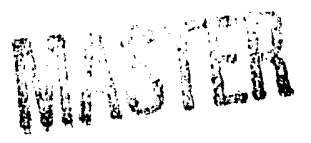


ARGONNE NATIONAL LABORATORY

Argonne Illinois 60439

Applied Mathematics Division

\section{WAUKEGAN STATION PLUME*}

I. K. Abu-Shumays

May 1971

Technical Memorandum No. 226

*Work performed under the auspices of the U.S. Atomic Energy Commission. This work was completed in June, 1970 but was not documented. It is reproduced here because of recent request for it and recent work based on it. 


\title{
WAUKEGAN STATION PLUME
}

\author{
I. K. Abu-Shumays
}

\section{ABST RACT}

The plume pattern is recognized as stochastic in nature and requires statistical analysis. A single relization of the Waukegan Station plume is studied with emphasis on its information content. Areas between isotherms at various depths are computed together with volumes of water in given temperature ranges above ambient; these measurements indicate the extent of the various parts of the plume together with the heat content of each part.

\section{INTRODUCTION}

In a previous report, ${ }^{1}$ we stressed the need for a statistical analysis of the spatial and temporal pattern of the plume and mentioned that such an analysis would be the most useful approach for the biologist and the chemist who are interested in the long term consequences of the hot water discharge at the vicinity of an outfall. The particular pattern of the plume at a given time under given meteorological and limological conditions is of interest to the mathematician as well as to the biologist. The mathematician would be interested in integrating (in the non-mathematical use of the term) various factors in order to arrive at the shape of the plume wind speed and direction, humidity, air temperature, shore currents, etc., together with bottom topography and outfall characteristics. The modes of the exchange characteristics (conduction, convection, 'vaporation, currents, turbulence, etc.) and conservation laws (energy, mass, momentum) are directly correlated with the volumes and surface areas of water in given temperature ranges in contact with the atmosphere, bottom sediments, ambient water as well as other warmer or colder parts of the plume.

The biologist might be interested, for example, in estimating the probability that a fish entering a given section of the plume would emerge unharmed.

Since it is impractical to measure all the relevant parameters that characterize the plume simultaneously, it is essential to be able to correlate 
various measurements (taking into account their fluctuations as well as expected error) in order to estimate with accuracy the shape of the plume at a given time and under given meteorological and limnological conditions.

\section{WAUKEGAN STATION PLUME}

Previously we have been critical of the study of Beer and Pipes ${ }^{2}$ of the Waukegan Station plume (Figs. 1-7), but let us for the moment assume that Figs. 2-7 (reproduced from Ref. 2) are accurate. We have calculated surface areas of water in a given temperature range of the plume at the various depths below the surface specified in Figs. 2-7. The results are given in Table $I$ and are used to estimate the volume of the warm plume water in a given temperature range above ambient. Since only six horizontal cross sections (Figs. 2-7) are used, volumes presented in $\mathrm{T}$ able II are very rough. The results in $\mathrm{T}$ able II were computed using the trapezoidal rule.

Figures $2-7$ and Tables I and II give reasonable estimates of the extent of the plume at various horizontal levels, and of the heat contents of its various sections (proportional to volume, for a given temperature).

One criticism of Beer and Pipes was that they did not take into account bottom topography (see Fig. 8) and did not measure currents (even crude values of currents will help in understanding the shape and form of the plume). If we are to assume for the sake of illustration that all the data given by Beer and Pipes are instantaneous or well correlated, then, taking into account bottom topography, we gat the horizontal cross sections of Figs. 9-18 which are different from Figs. 2-7 of Beer and Pipes, especially in the shallow region. We would expect, according to Fig. 8 , that the plume would first turn left due to the 3-4 ft. bottom sediments which act as a barrier, then would turn right due to the $4 \mathrm{ft}$. shallow sediments on the northern side of the plume. Had we known the direction and speed of currents in this range we would have been more certain of the actual direction the plume takes. However, we still feel that Figs. 9-18 
are more representative of the plume than Figs. 2-7. Table III represents the areas between isotherms of various depths and Table IV gives the volumes of water in the temperature range specified. Note that we have eliminated temperature isotherms at $1^{\circ} \mathrm{F}$ above aublents from contours of depth 10 feet or less. This is because we do not expect to get sharply defined boundaries from the available data. ${ }^{2-4}$

\section{CONCLUDING REMARKS}

It is realtively easy to write a computer program that would convert horizontal isotherm contours to volumes of warm water at a given temperature range as well as interfacial surfaces with the atmosphere, bottom sediments or surrounding colder or warmer plume waters. If in addition one has an 1dea of velocity profiles (from current measurements) then one should be able to compute heat exchanges, volumes of ambient waters entrained in a given range of the plume together with a number of valuable exchange coefficients. This is planned for our future studies* and has not been done at the present because of the time limitations imposed on this report, but mainly because the empirical data available are admittedly insufficient for a meaningful analysis. We point out for example that at the present the empirical data do not include enough measurements to define the boundaries of the plume and in particular the degree of spread of the jet in the horizontal direction parallel to shore. Thus, on the basis of available data one can increase or decrease the width of the plume (see Figs.) to fit practically any one of a number of available analytic models. ${ }^{3}$

Finally, we stress again the need for current measurements. Internal ambient currents in an east south-east direction would, for example, explain the bifercation of the plume at depth greater than $5 \mathrm{ft}$. The bottom contours may also induce eddy currents that would result in plume bifercation.

*J. Carson and $P$. Gustafson also suggest evaluating the excess heat loss to the air from known surface areas of various temperatures above ambient, air temperature, humidity, wind speed and direction. 
RE FE RENCES

1. I. K. Abu-Shumays, "Initial Objectives of On-Site Empirical Modelling of Thermal Plumes: A Preliminary Evaluation of a River-Site and a Lake-Side Thermal P1ume," ANL-AMD TM-198, May 1970.

2. L. P. Beer and W. O. Pipes, "A Practical Approach: Environmental Effects of Condenser Water Discharge In Southwest Lake Michigan," Industrial BIO-TEST Lab. Inc., no date given.

3. T. R. Sundaram, C. C. Easterbrook, K. R. Piech, and G. Rudinger, "An Investigation of the Physical Effects of Thermal Discharges Into Cayuga Lake (Analytical Study)," CAL Report No. VT-2616-0-2, November 1969 .

4. U. S. Department of the Interior, "Preliminary Sampling Survey, Waukegan and Zion Power Plant Sites," FWQA, Lake Michigan Basin Office, Chicago, April 1970. 


\section{Table I}

Areas Between Temperature Isotherm Corresponding to F1gures 2-7. (Area Measured in Units of $10^{4} \mathrm{ft}^{2} . *$ )

\begin{tabular}{|c|c|c|c|c|c|c|c|}
\hline \multirow{2}{*}{$\begin{array}{r}\text { Depth } \\
(f t)\end{array}$} & \multicolumn{6}{|c|}{ Temperature Range $\left({ }^{\circ} \mathrm{F}\right)$} & \multirow{2}{*}{$\begin{array}{l}\text { Welght for } \\
\text { Volume } \\
\text { Measurements }\end{array}$} \\
\hline & $55-57$ & $53-54$ & 53 & $49-52$ & $49-50$ & 49 & \\
\hline 1 & 12.8 & 14.3 & & 230 & & & 2 \\
\hline 4 & 12.4 & 14.5 & & 165 & & & 4 \\
\hline 8 & 2.81 & 7.79 & & 94.8 & & & 3 \\
\hline 10 & & & 4.16 & 77.6 & & & 3 \\
\hline 14 & & & & & 24.7 & & 4 \\
\hline 18 & & & & & & 3.24 & 3 \\
\hline
\end{tabular}

*Measurements were made by an OTT-PLANIMETER (each area represents an average of five measurements).

Table II

Volume of the Portions of the Plume

in the Specified Temperature Ranges.*

\begin{tabular}{|c|c|}
\hline Temperature Range & Volume \\
\hline $55-57$ & $8.36 \times 10^{5} \mathrm{ft}^{3}$ \\
$53-54$ & $1.22 \times 10^{6} \mathrm{ft}^{3}$ \\
$49-52$ & $1.75 \times 10^{7} \mathrm{ft}^{3}$ \\
\hline
\end{tabular}

*Volume versus temperature above ambient would be useful blologically. We note that the ambient temperature at the time of the measurements varied with depth and location from $45^{\circ} \mathrm{F}$ to $48^{\circ} \mathrm{F}$. 
Table III

Areas Between Temperature Isotherms Corresponding to Figures 9-18. (Area Measured in Units of $10^{4} \mathrm{fr}^{2}, *$ )

\begin{tabular}{|c|c|c|c|c|c|c|c|c|c|}
\hline \multirow{2}{*}{$\begin{array}{r}\text { Depth } \\
\text { (ft })\end{array}$} & \multicolumn{9}{|c|}{ Tamperature Range $\left({ }^{\circ} \mathrm{F}\right)$} \\
\hline & 57 & $55.5-56$ & 55 & 54 & 53 & 52 & $50-52$ & 50 & 49 \\
\hline 0 & 2.88 & 1.76 & 7.84 & 9.44 & 8.48 & & 162 & & \\
\hline 2 & 2.88 & 2.24 & 8.32 & 8.32 & 8.00 & & 148 & & \\
\hline 4 & 2.88 & 2.08 & 8.64 & 8.48 & 5.60 & & 96.8 & & \\
\hline 6 & 2.08 & 1.76 & 2.40 & 6.88 & 2.92 & & 85.9 & 51.2 & \\
\hline 8 & & 1.44 & 2.88 & 6.56 & 5.60 & & 65.6 & & \\
\hline 10 & & & & & 11.2 & & 38.2 & & \\
\hline 12 & & & & & 1.92 & 5.76 & 33.0 & & 20.3 \\
\hline 14 & & & & & & & & 14.1 & 11.2 \\
\hline 16 & & & & & & & & 7.36 & 16.3 \\
\hline 18 & & & & & & & & & 5.60 \\
\hline
\end{tabular}

*Measurements were made by an OTT-PLANIMETER

Table IV

Volume of the Portions of the Plume in the Specified Temperature Ranges.

\begin{tabular}{|c|c|}
\hline Temperature Range & Volume \\
\hline 57 & $1.6 \times 10^{5} \mathrm{ft}^{3}$ \\
$55.5-56$ & $1.7 \times 10^{5} \mathrm{ft}^{3}$ \\
55 & $5.2 \times 10^{5} \mathrm{ft}^{3}$ \\
54 & $7.0 \times 10^{5} \mathrm{ft}^{3}$ \\
53 & $7.9 \times 10^{5} \mathrm{ft}^{3}$ \\
$50-52$ & $1.14 \times 10^{7} \mathrm{ft}^{3}$ \\
\hline
\end{tabular}




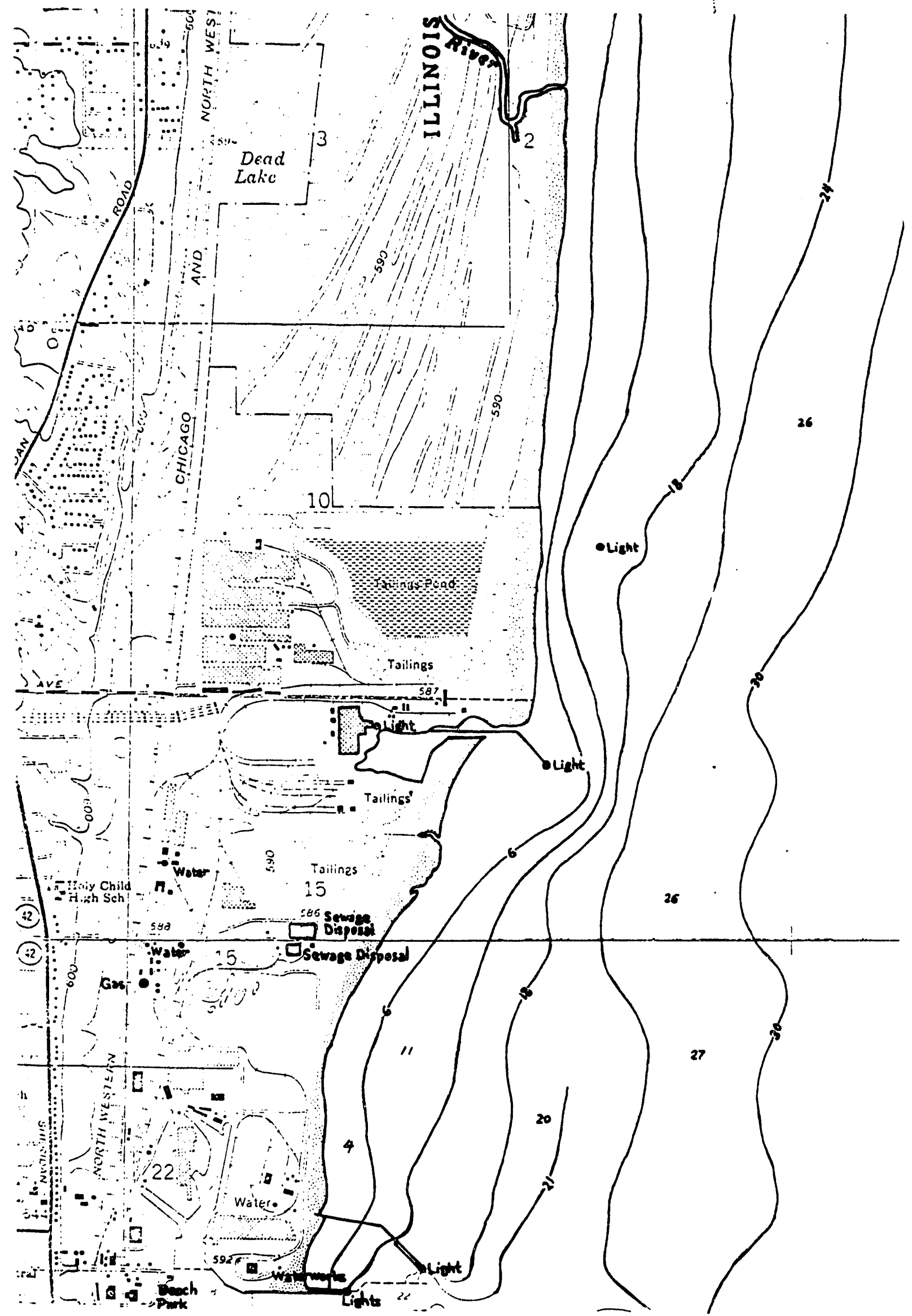

Fig.1. Waukegan Station. 


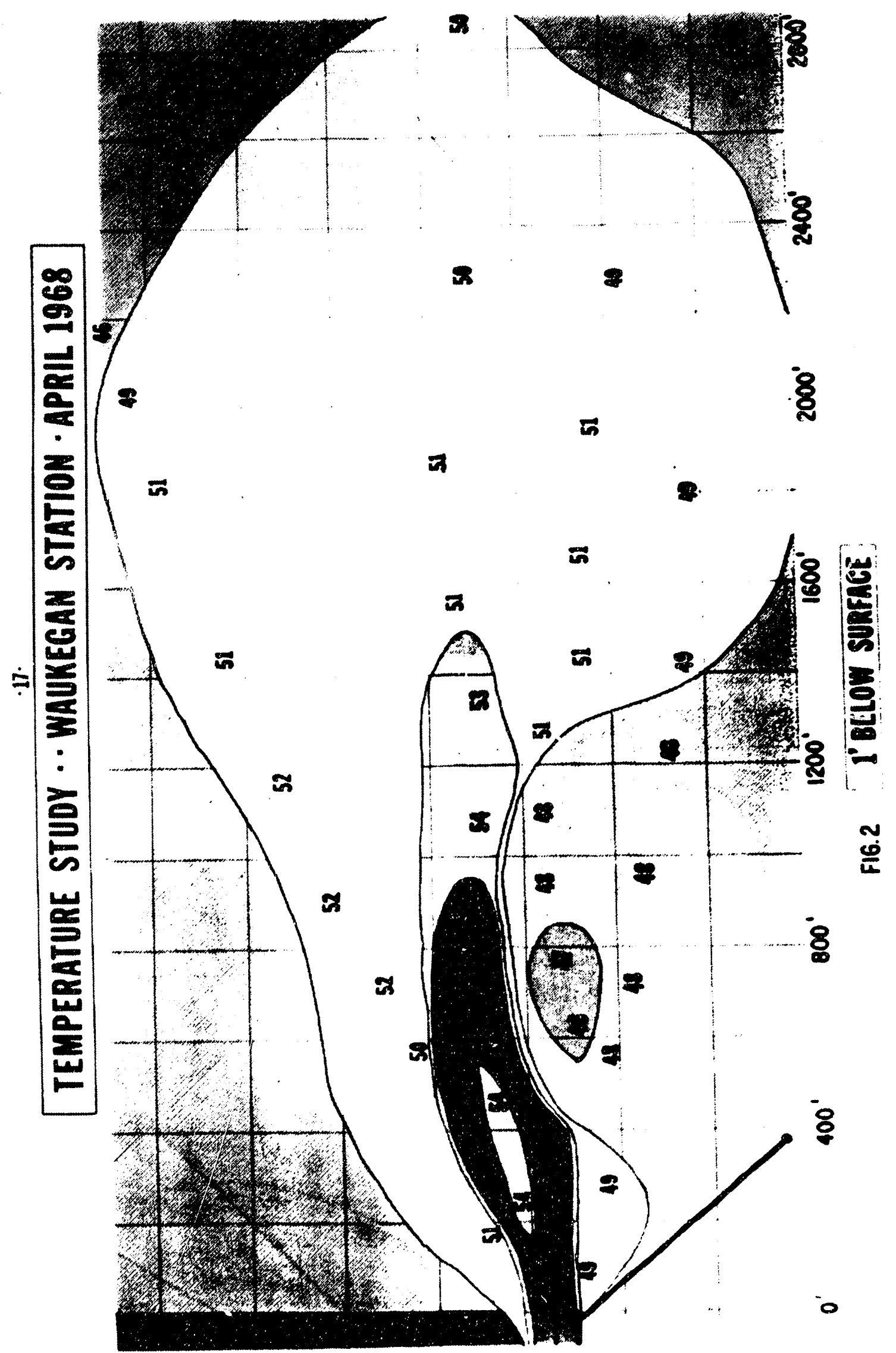




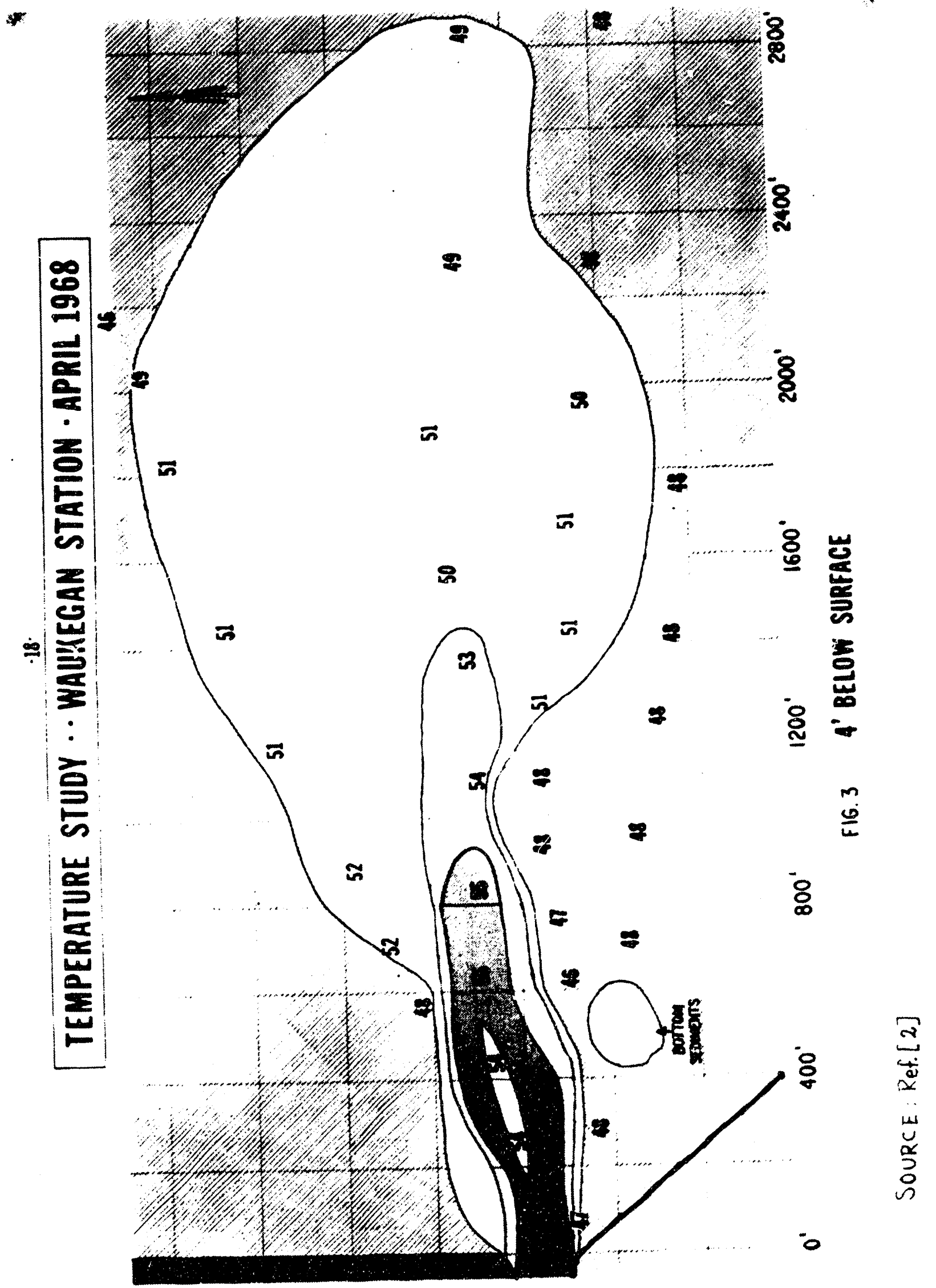




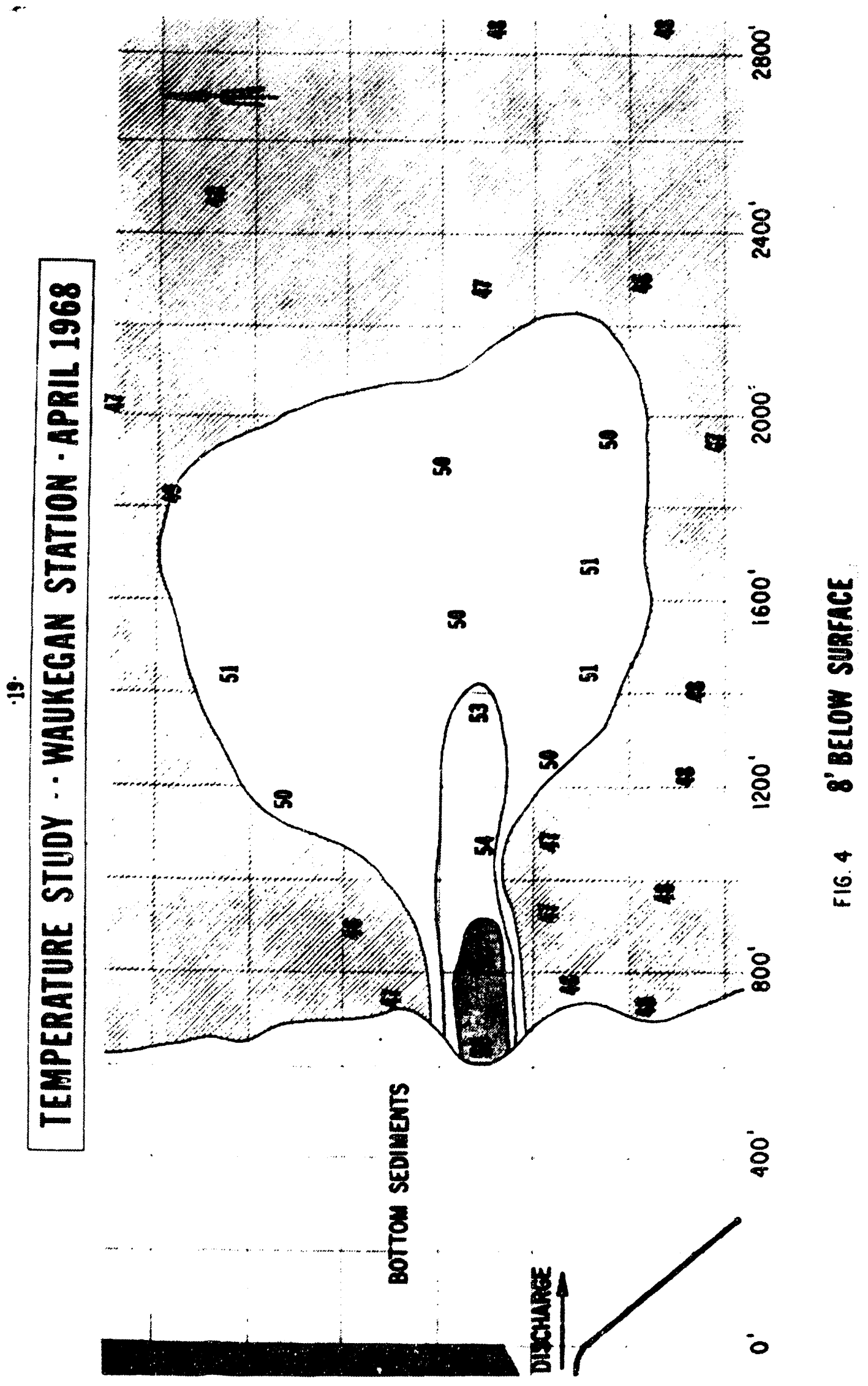

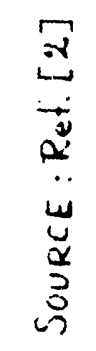




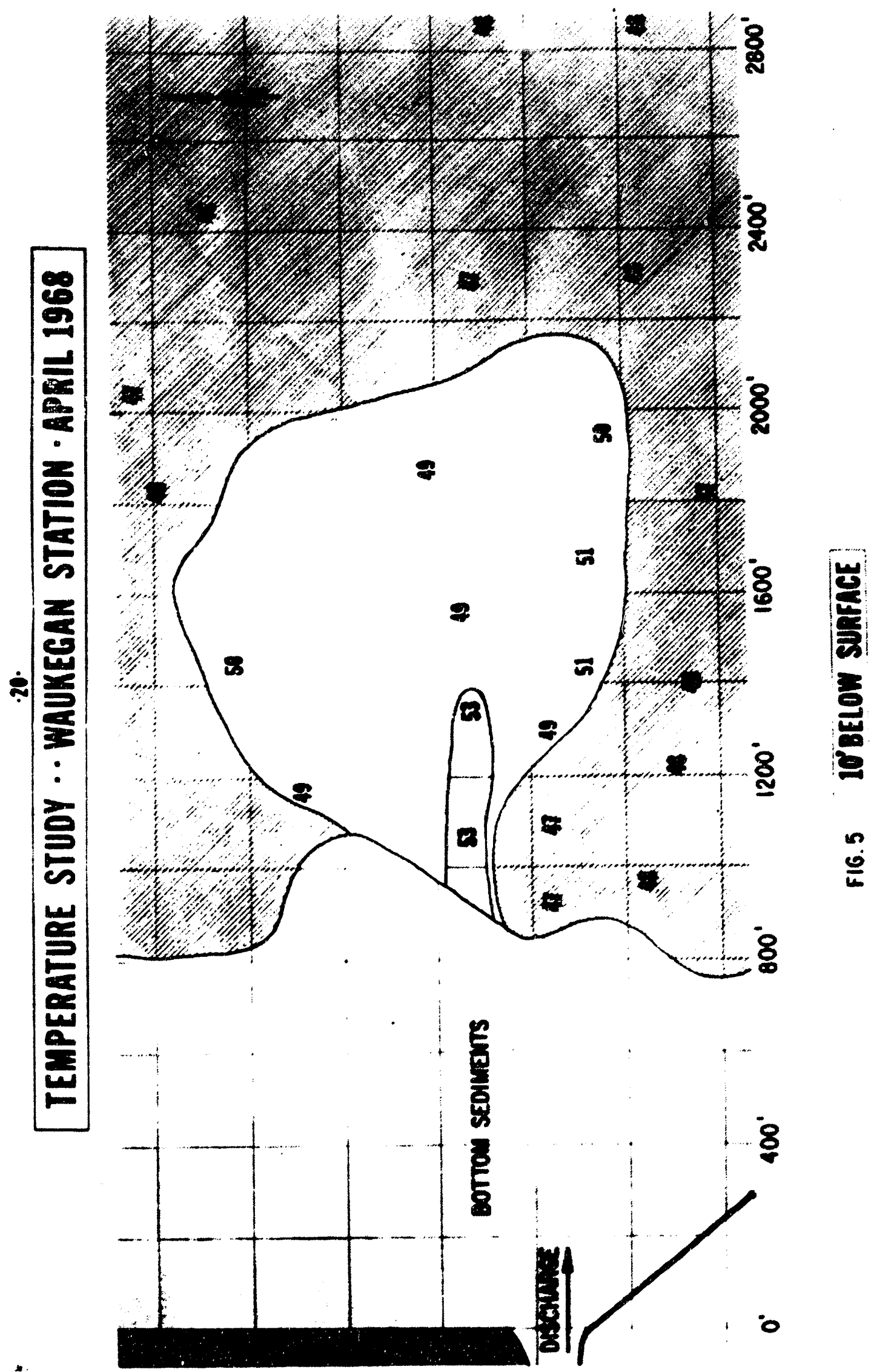

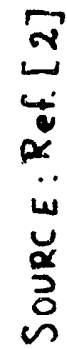




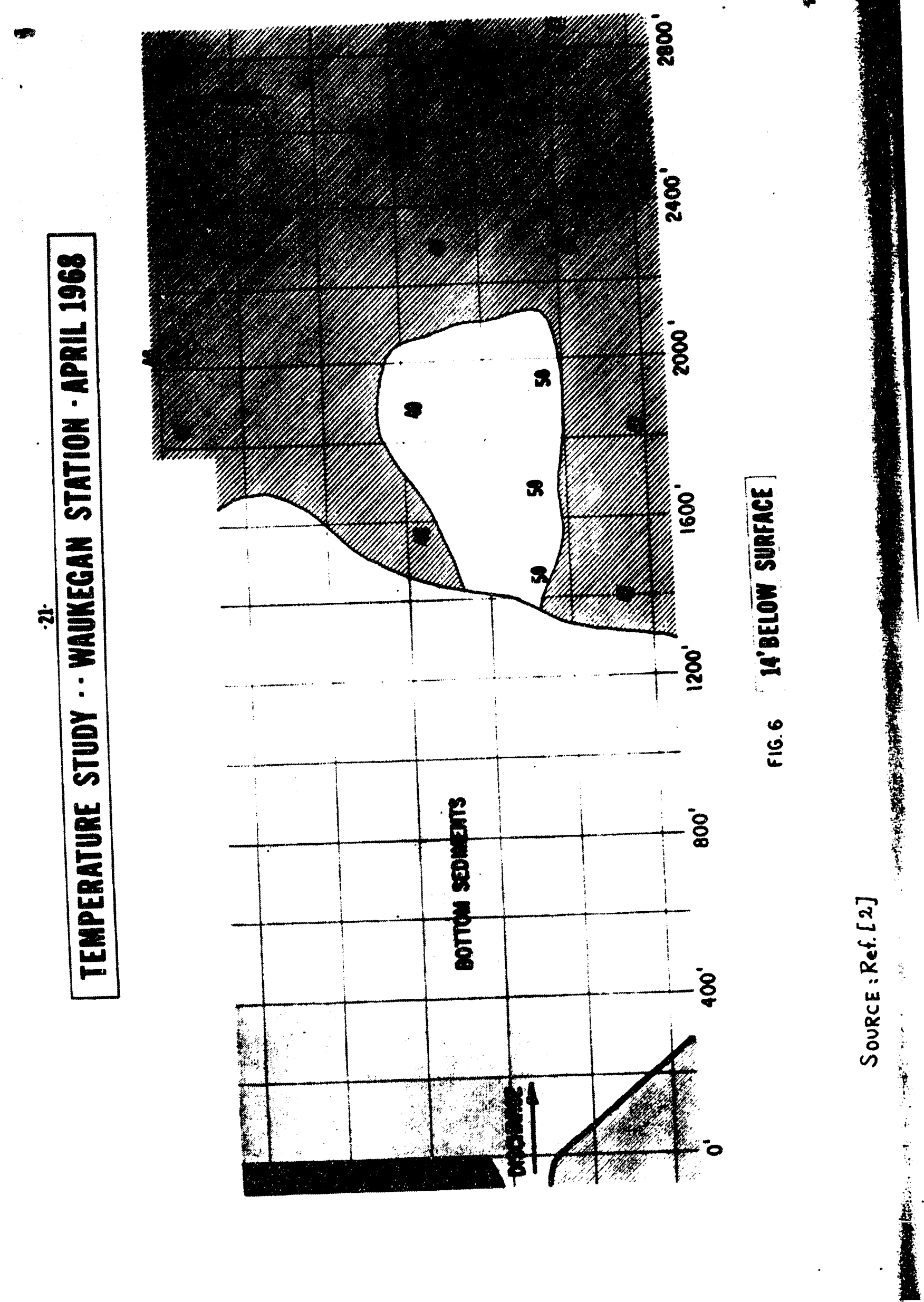




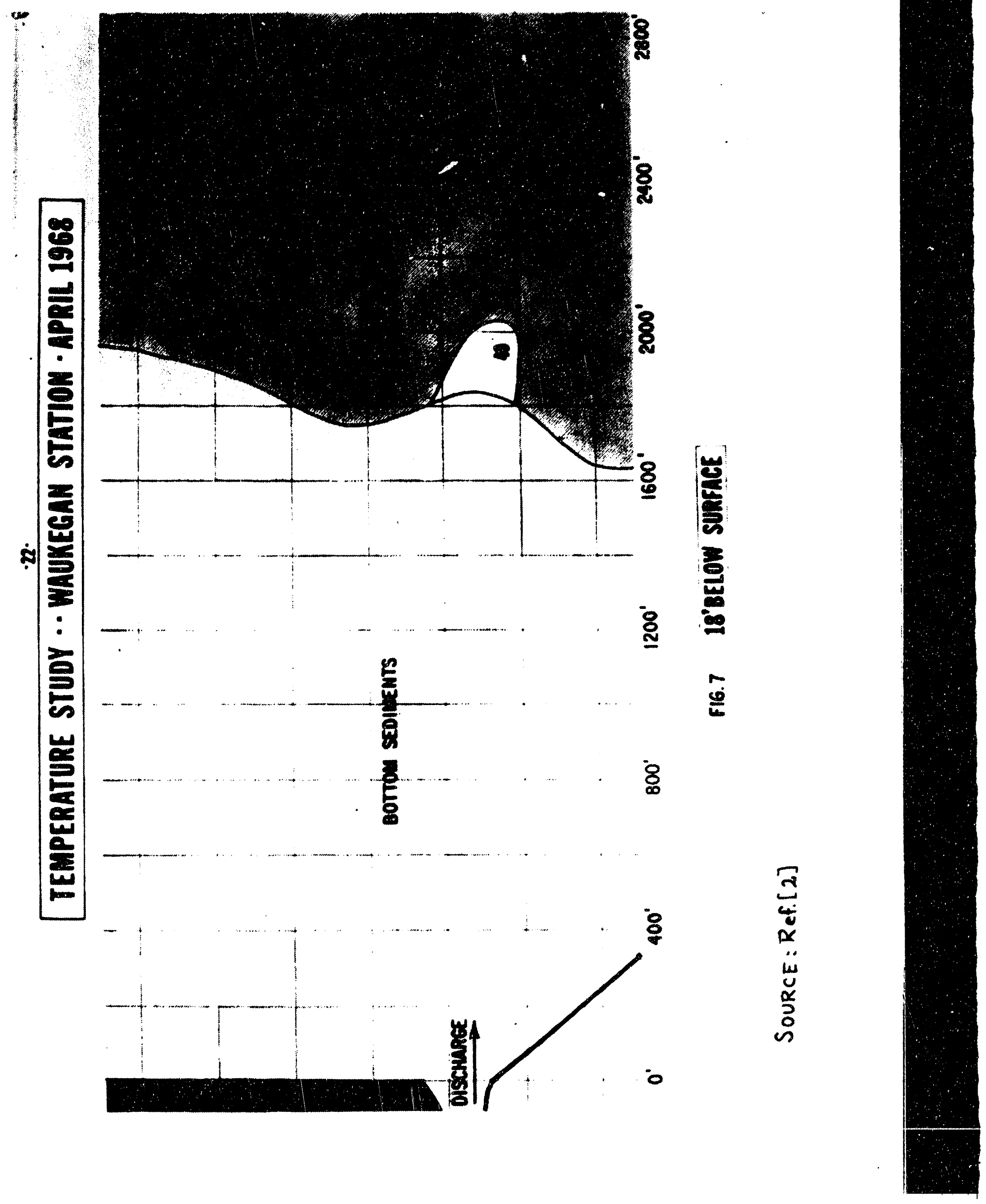




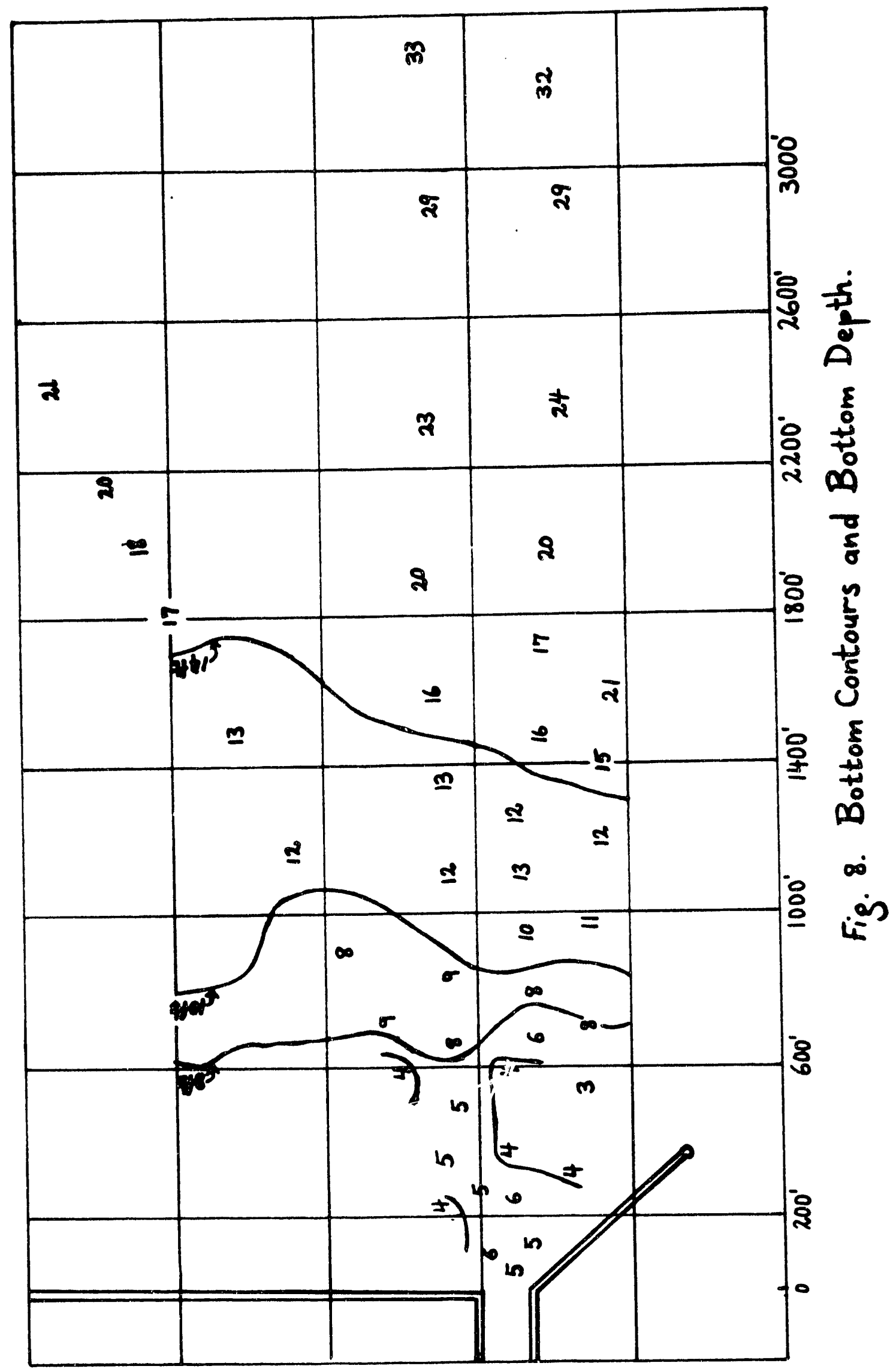




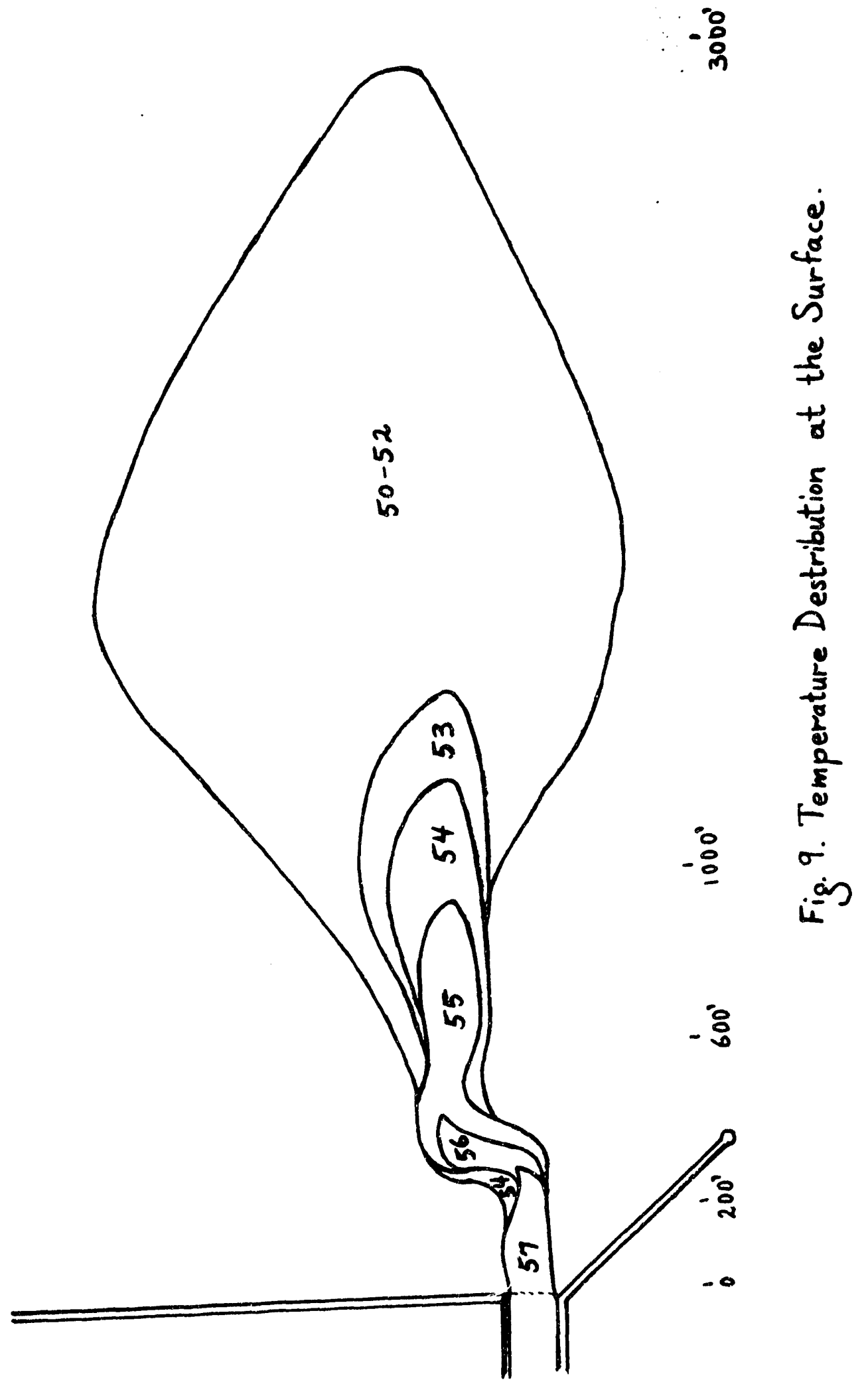

I 


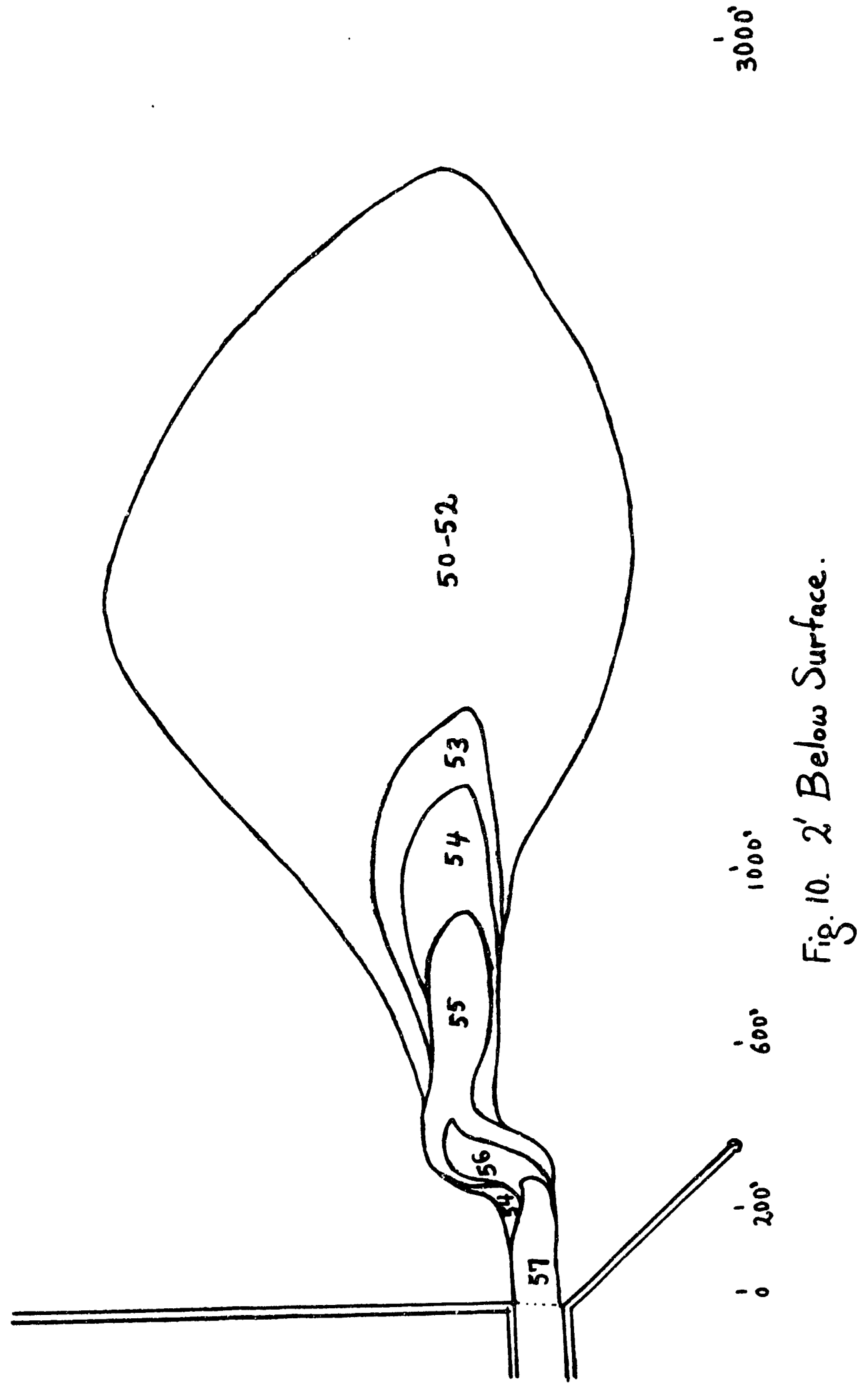


-。ํㅁㅇ

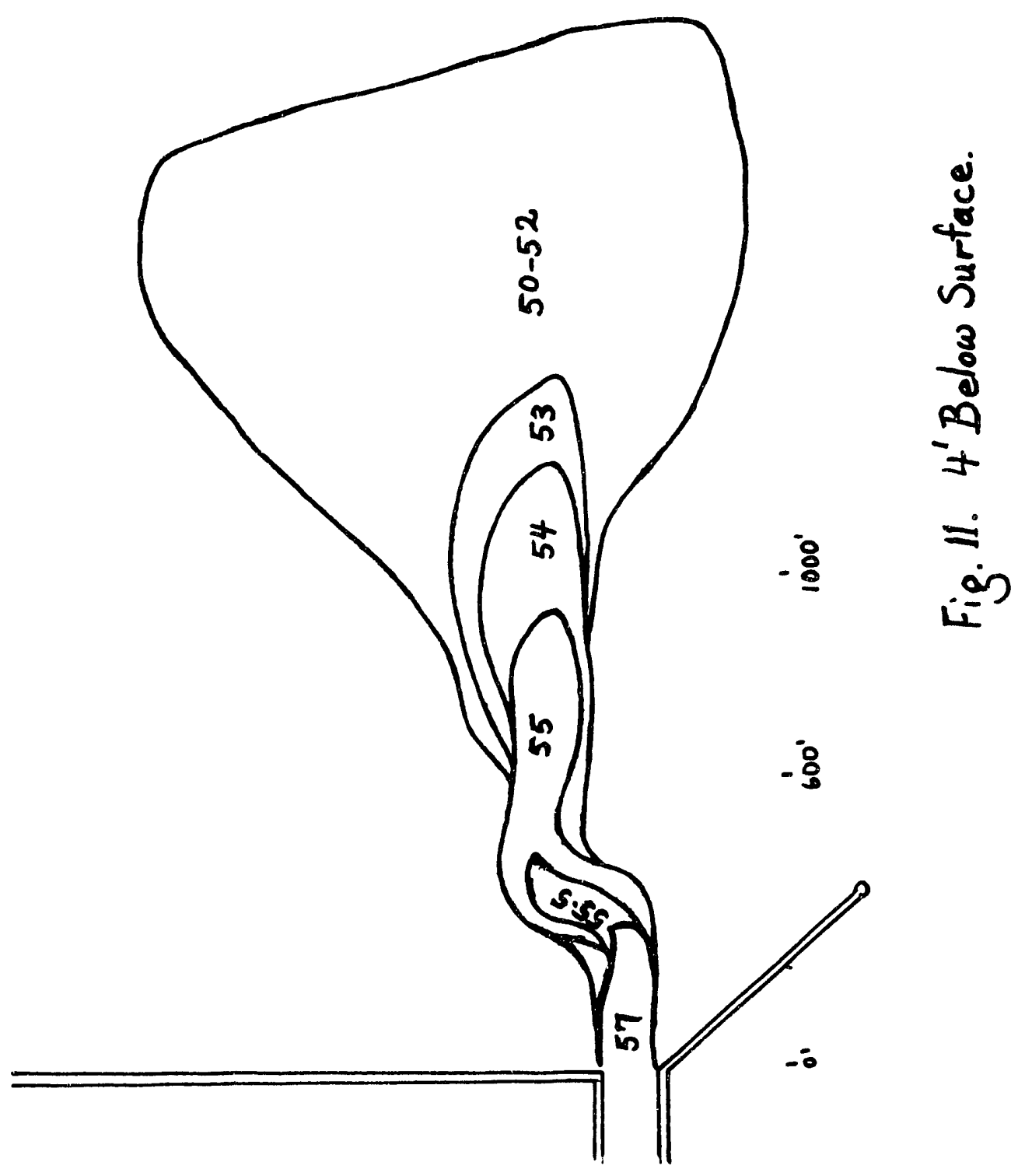


-。용
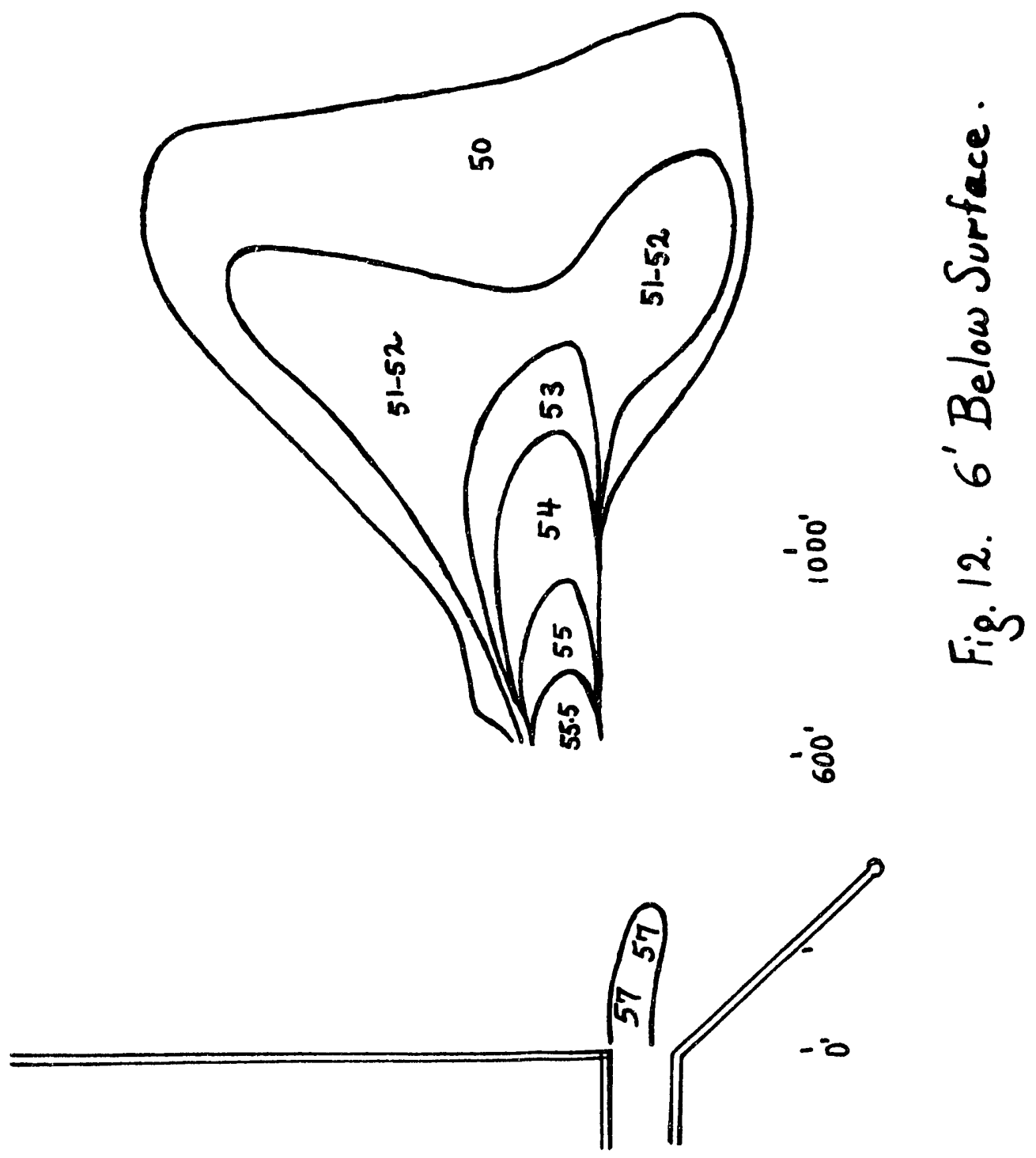
兽
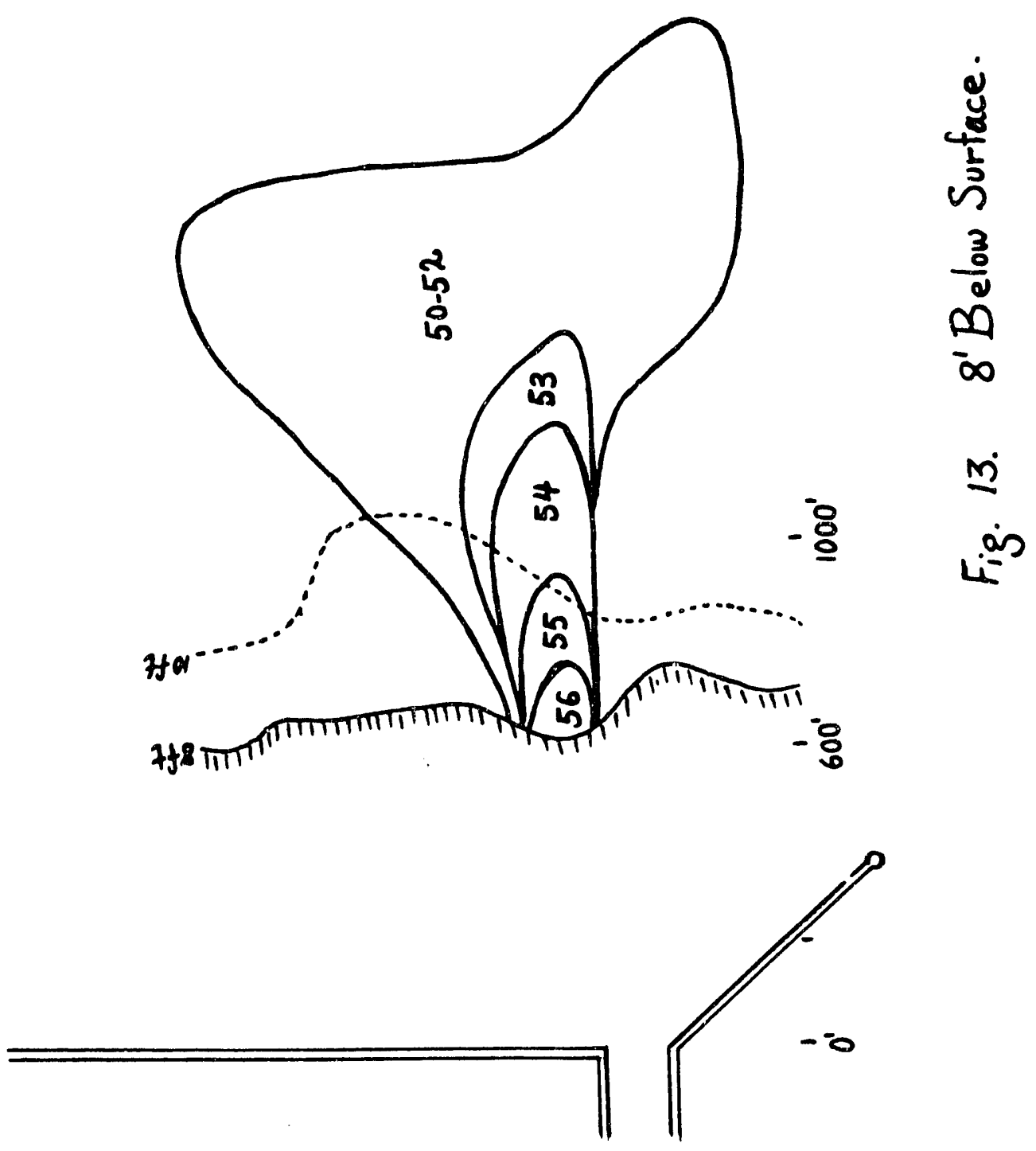
-

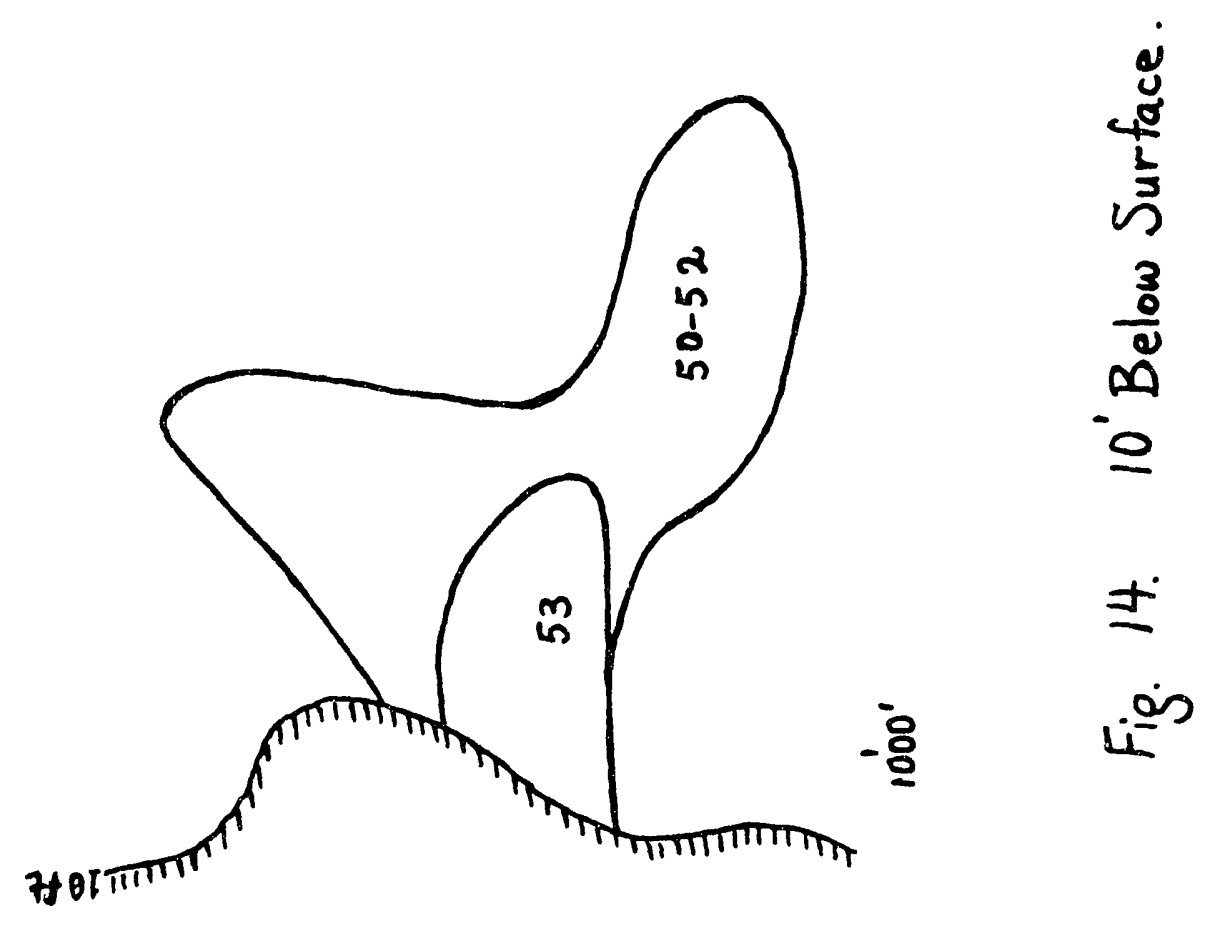

-8

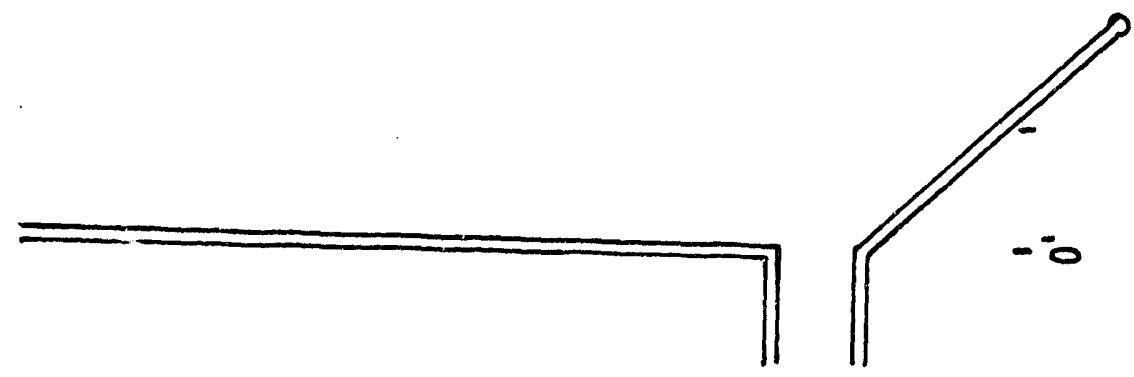


-迹

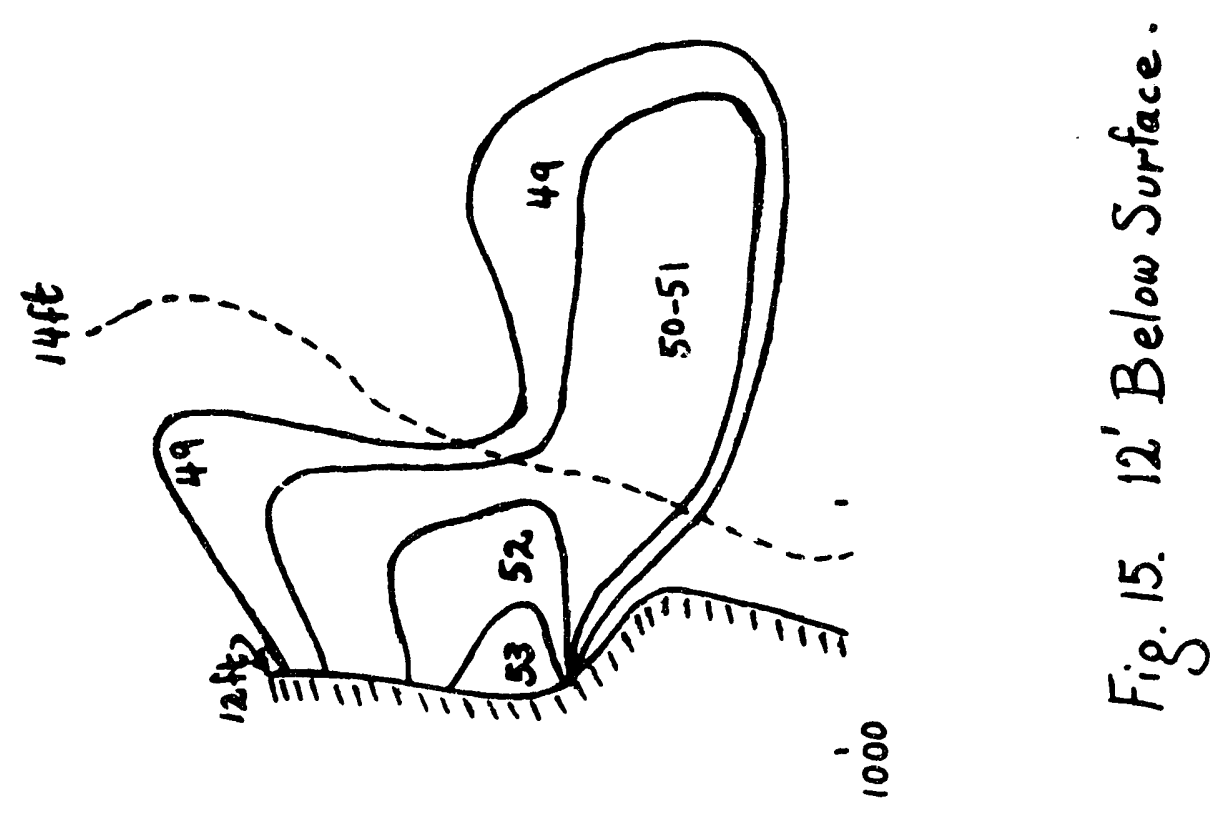

-\%

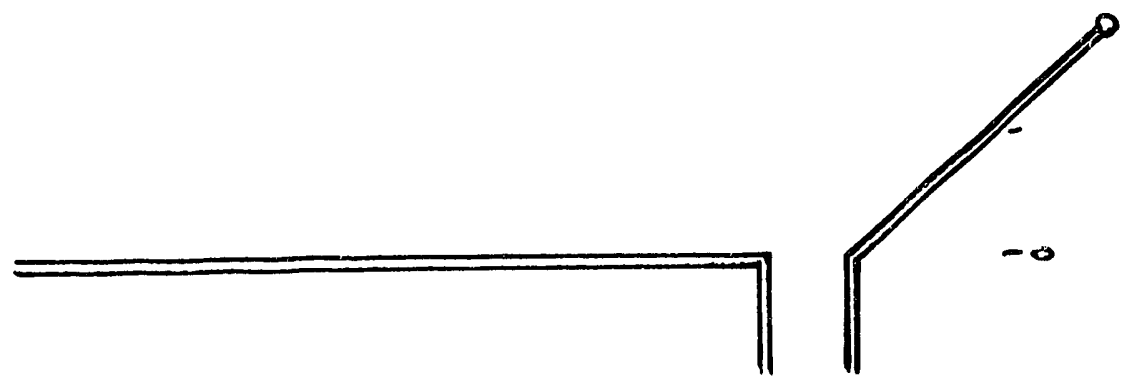


-

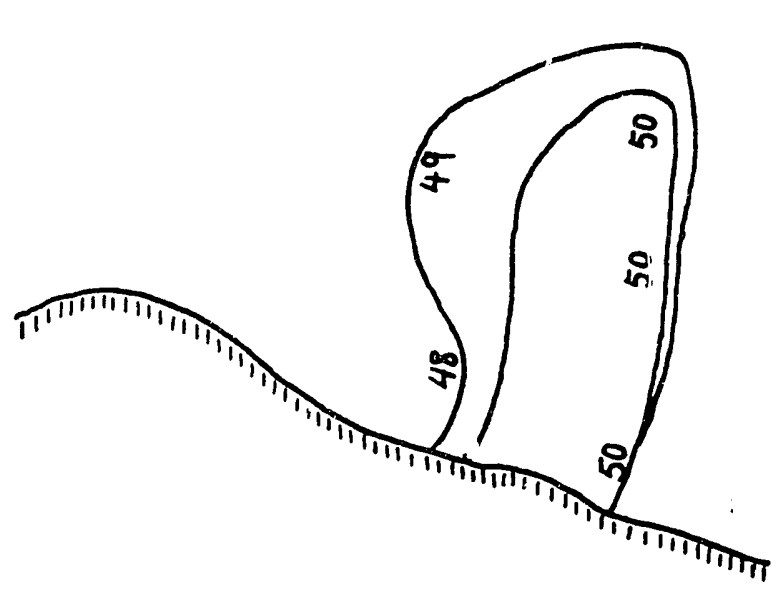

\begin{tabular}{l}
0 \\
\multirow{8}{3}{} \\
$\frac{1}{3}$
\end{tabular}

온

a

I

-용

1

is

$-8$

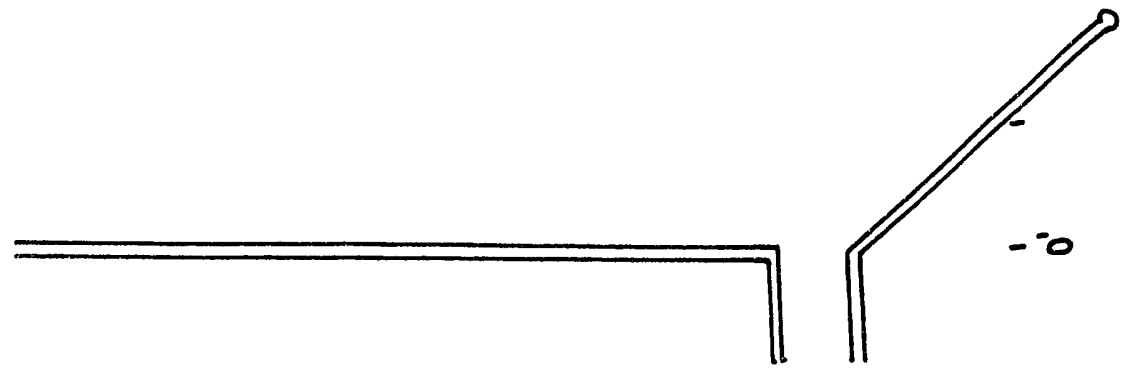


-

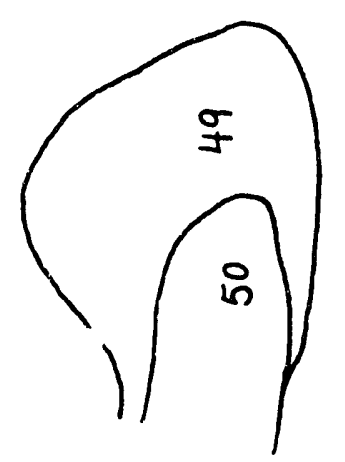

$\frac{d}{\frac{j}{o}}$

은

$M$

-

$\Sigma$

is

is

- 음

-8

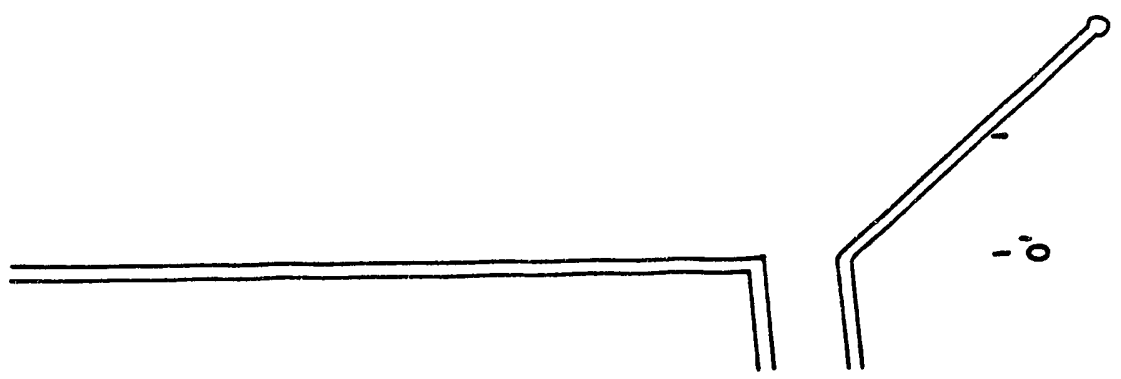


-0
-8
0
$m$

-8
-8
-8

$\begin{array}{rr}-8 & 0 \\ -\frac{1}{2} & \frac{u}{4} \\ & \frac{3}{5} \\ & 0\end{array}$

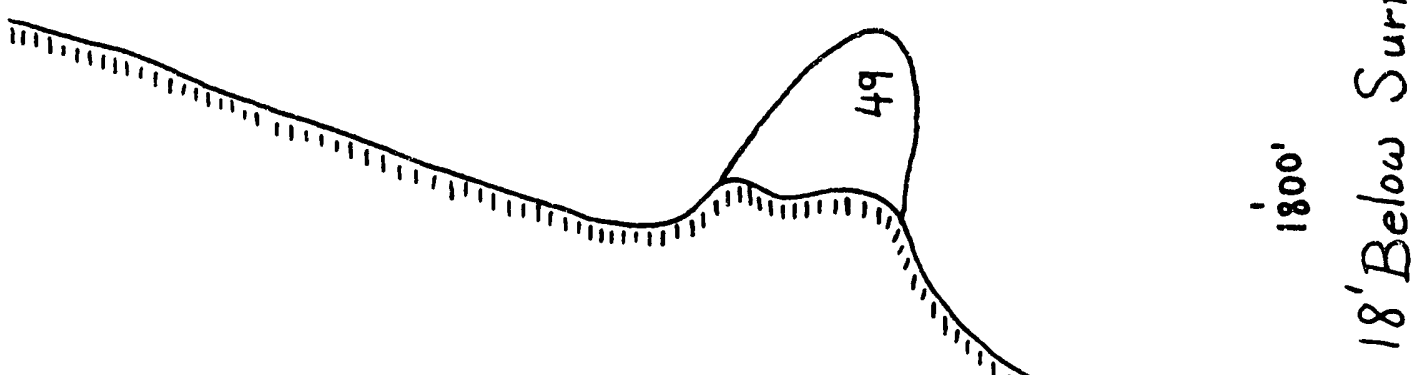

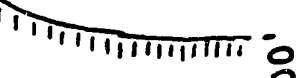

- $\frac{\infty}{\text { 五 }}$

$\begin{array}{r}-8 \\ -8 \\ \hline\end{array}$

$-8$

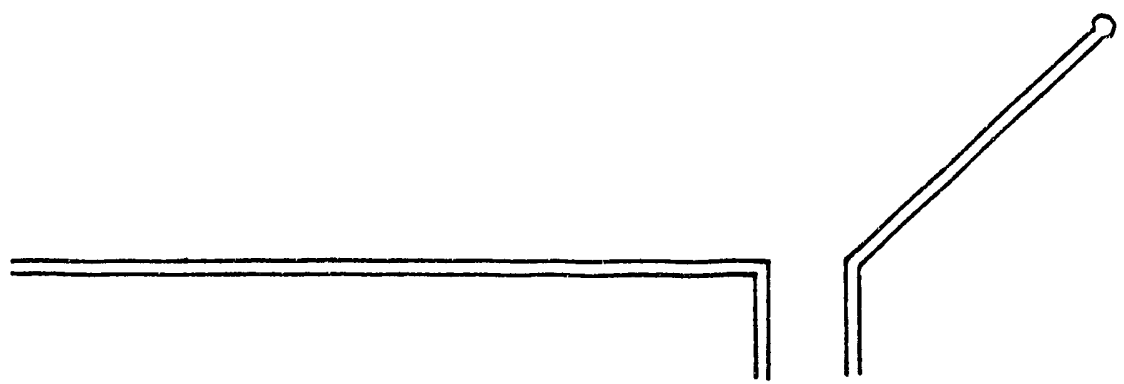

- 8

- 0 

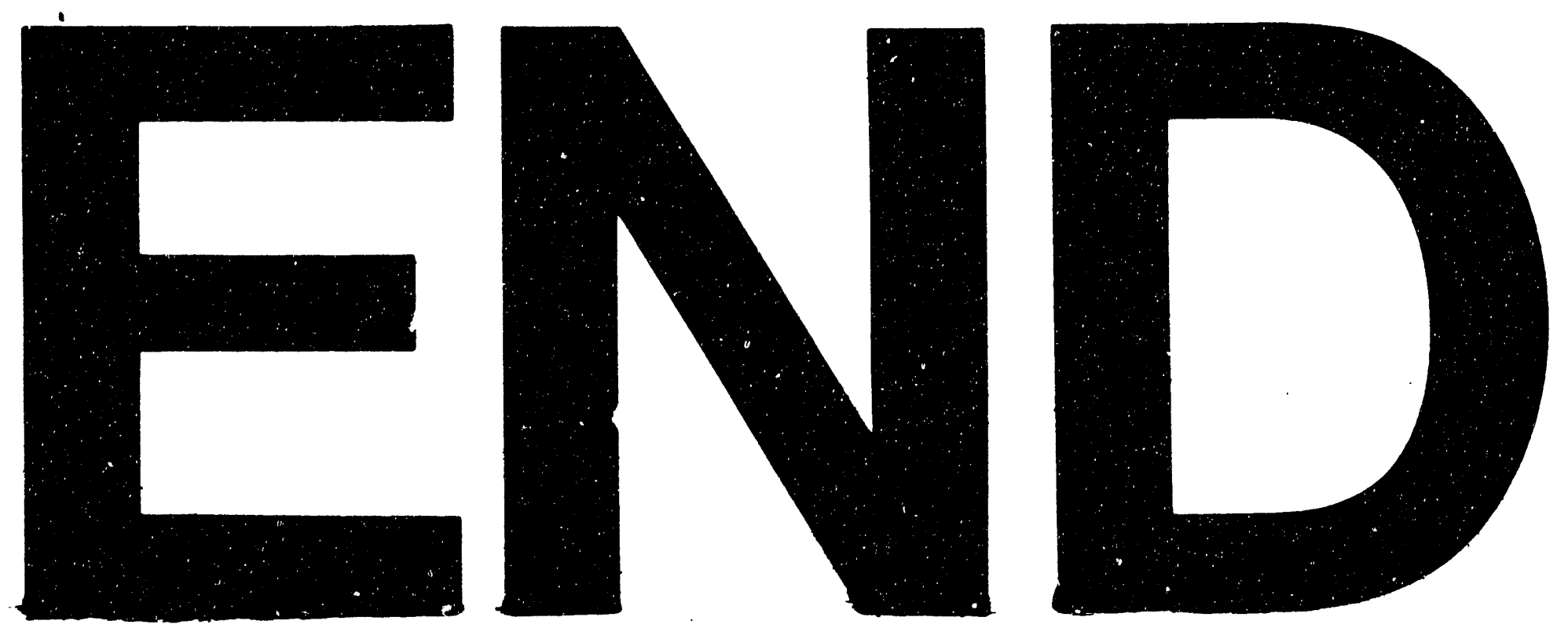

$x$

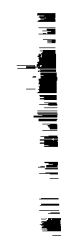
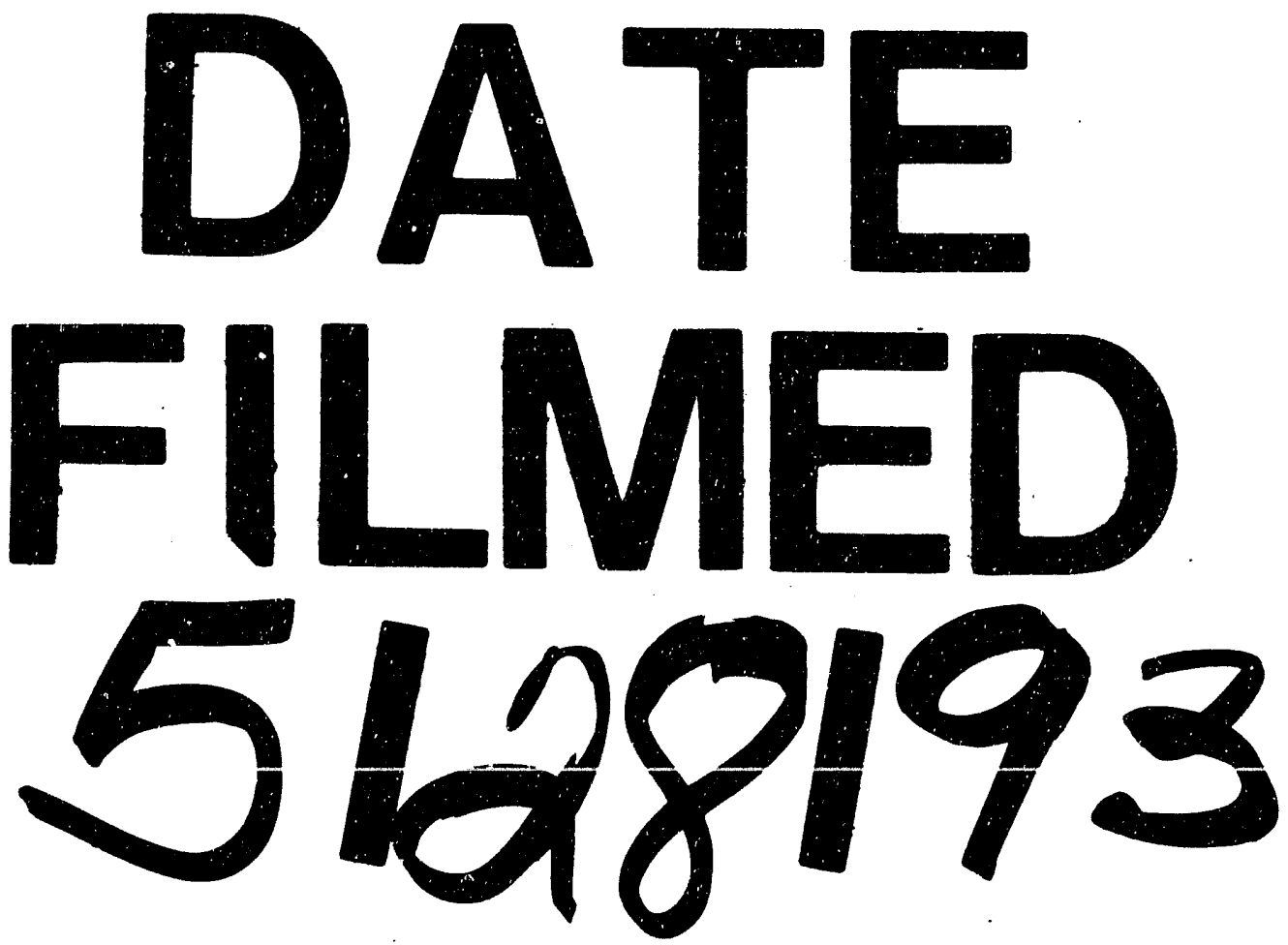
